\title{
Analisis pengaruh pajak daerah dan retribusi daerah terhadap belanja daerah dan pertumbuhan ekonomi Provinsi Jambi
}

\author{
Tri Setyo Budi*; Selamet Rahmadi; Parmadi
}

Prodi Ekonomi Pembangunan Fak.Ekonomi dan Bisnis, Universitas Jambi

*E-mail korespondensi: trisetyobudi9595@gmail.com

\begin{abstract}
The research objective is to see and analyze: 1). The development of regional taxes, local levies, regional spending, and economic growth as seen from the value of PDRB Jambi Province during the period 2002-2018, 2). The effect of local taxes and levies on regional spending in Jambi Province during 2002-2018 and 3). The influence of local taxes and levies on economic growth in Jambi Province during the period 2002-2018. The analysis method in this study uses quantitative and descriptive analysis methods, namely development, semilog, and double logarithmic multiple regression analysis. The research results during the years 2002-2018, obtained: 1). The average regional tax increased by 17.03 percent, the average provincial levy increased by 16.49 percent, the average regional expenditure increased by 16.04 percent, and economic growth grew by 5.76 percent. 2). Partially (individually) or collectively, local taxes and levies have a positive and significant effect on spending on the Jambi Province at $\alpha=5 \%$ during the period 2002-2018 and 3). Partially (individually) or collectively, local taxes and levies have a positive and significant effect on economic growth in Jambi Province at $\alpha=5 \%$ during the period 2002-2018.
\end{abstract}

Keywords: Local taxes, Regional levies, Regional expenditures, Economic growth

\begin{abstract}
Abstrak
Tujuan penelitian adalah untuk mengetahui dan menganalisis: 1). Perkembangan pajak daerah, retribusi daerah, belanja daerah dan pertumbuhan ekonomi yang dilihat dari nilai PDRB Provinsi Jambi selama periode tahun 2002-2018, 2). Pengaruh pajak daerah dan retribusi daerah terhadap belanja daerah Provinsi Jambi selama periode Tahun 2002-2018 dan 3). Pengaruh pajak daerah dan retribusi daerah terhadap pertumbuhan ekonomi Provinsi Jambi selama periode tahun 2002-2018. Metode analisis dalam penelitian ini menggunakan metode analisis deskriptif dan kunatitatif yaitu perkembangan, analisis regresi berganda semi log dan double logaritma. Hasil penelitian selama tahun 2002-2018, diperoleh: 1). Rata-rata pajak daerah meningkat 17,03 persen, rata-rata retribusi daerah meningkat 16,49 persen, ratarata belanja daerah meningkat 16,04 persen dan pertumbuhan ekonomi tumbuh rata-rata 5,76 persen. 2). Secara parsial (individu) maupun secara bersama-sama, pajak daerah dan retribusi daerah berpengaruh positif dan signifikan terhadap belanja daerah Provinsi Jambi pada $\alpha=$ $5 \%$ selama periode tahun 2002-2018 dan 3). Secara parsial (individu) maupun secara bersama-sama, pajak daerah dan retribusi daerah berpengaruh positif dan signifikan terhadap pertumbuhan ekonomi Provinsi Jambi pada $\alpha=5 \%$ selama periode tahun 2002-2018.
\end{abstract}

Kata kunci: Pajak daerah, Retribusi daerah, Belanja daerah, Pertumbuhan ekonomi 


\section{PENDAHULUAN}

Indikator mengukur keberhasilan pembangunan yang dilaksanakan suatu negara/daerah salah satu caranya adalah melalui pertumbuhan ekonomi. Pertumbuhan ekonomi itu sendiri dapat diartikan sebagai gambaran mengenai dampak dari kebijakankebijakan pemerintah yang dilaksanakan dalam bidang ekonomi dan menggambarkan tingkat perkembangan sesuatu negara/daerah dengan melihat persentasi pertambahan pendapatan nasional riil. (Arsyad, 2010). Pertumbuhan ekonomi suatu negara/daerah terlihat dari meningkatnya Produk Domestik Bruto (PDB)/ Produk Domestik Regional Bruto (PDRB).

Pertumbuhan ekonomi di Provinsi Jambi selama empat tahun terakhir yang diukur dari PDRB atas dasar harga konstan 2010, yaitu dari tahun 2015-2018 menurut BPS Provinsi Jambi mengalami peningkatan yang berfluktuasi. Selama tahun tersebut laju pertumbuhan ekonomi Provinsi Jambi, rata-rata meningkat sebesar 4,48 persen. Pada tahun 2015 laju pertumbuhan ekonomi meningkat sebesar adalah sebesar 4,21 persen, pada atahun 2016 laju pertumbuhan ekonomi meningkat dari tahun sebelumnya menjadi sebesar 4,37 persen, pada tahun 2017 laju pertumbuhan meningkat lagi menjadi sebesar 4,60 persen dan pada tahun 2018 laju pertumbuhan ekonomi di Provinsi Jambi meningkat dari tahun sebelumnya menjadi sebesar 4,74 persen.

Peningkatan Pendapatan Asli Daerah (PAD), khususnya dari pajak daerah dan retribusi daerah diupayakan melalui program intensifikasi dan ekstensifikasi terhadap wajib pajak dan retribusi daerah. Intensifikasi dan Ekstensifikasi pengelolaan pendapatan daerah sangat di pengaruhi oleh Peraturan Perundang-undangan yang berlaku terutama berkaitan dengan PAD, dana perimbangan serta lain-lain pendapatan daerah yang sah. (Halim dan Kusufi, 2015). Ketentuan peraturan/perundang-undangan ditegaskan, bahwa penerimaan pendapatan tidak boleh memberatkan masyarakat dan menghambat pertumbuhan ekonomi. (Idris, 2016).

Pajak daerah yang dapat dipungut provinsi, termasuk Provinsi Jambi bersumber dari pajak kendaraan bermotor, bea balik nama kendaraan bermotor, pajak bahan bakar kendaraan bermotor, pajak kendaraan diatas air, pajak air permukaan dan pajak air bawah tanah. (Waluyo, 2016). Sementara pada retribusi daerah bersumber dari retribusi jasa umum, retribusi jasa usaha dan retribusi perizinan tertentu. (Siahaan, 2013).

Berdasarkan Badan Pusat Statistik (BPS) Provinsi Jambi selama tahun 2015-2018, pendapatan daerah Provinsi Jambi mengalami peningkatan. Pendapatan daerah Provinsi Jambi tahun 2015 adalah Rp. 3.229.704.823.876,26 dan meningkat di tahun 2018 menjadi sebesar Rp. 4.412.464.565.599,21 atau meningkat sebesar 155,01 persen. Peningkatan pendapatan daerah dari tahun 2015 ke tahun 2018 terjadi akibat meningkatnya PAD sebesar 210,94 persen, dari Rp.1.419.079.798.364,00 pada tahun 2015 menjadi Rp.4.412.464.565.352,00 pada tahun 2018, dana perimbangan meningkat dari Rp.1.419.079.798.364,00 di tahun 2015 menjadi Rp.2.745.221.985.751,00 di tahun 2018 atau naik sebesar 93,45 persen dan penerimaan lain-lain pendapatan yang sah mengalami penurunan sebesar 97,85 persen, yaitu dari Rp.496.401.997.365 pada tahun 2015 menjadi Rp.10.673.000.000,00 di tahun 2018.

PAD sebagai sumber penerimaan asli daerah di Provinsi Jambi, ternyata memiliki peningkatan paling besar di banding sumber pendapatan daerah lainnya dari tahun 2015 ke tahun 2018. Selama tahun 2015-2018, sumber-sumber PAD Provinsi Jambi yaitu pajak daerah meningkat sebesar 10,72 persen, yaitu dari Rp. 1.241.237.021.592,00 pada tahun 
2015 menjadi Rp. 1.374.289.409.825,00 di tahun 2018. Penerimaan retribusi daerah meningkat sebesar 100,02 persen, yaitu yaitu dari Rp. 1.010.318.9708,00 pada tahun 2015 menjadi Rp. 20.208.218.743,00 pada tahun 2018. Hasil perusahaan milik daerah dan pengelolaan kekayaan daerah yang dipisahkan meningkat sebesar 57,79 persen, yaitu dari Rp. 19.336.663.936,00 pada tahun 2015 menjadi Rp. 30.511.005.690,00 di tahun 2018. Sementara penerimaan lain-lain PAD yang sah meningkat sebesar 479,54 persen, yaitu yaitu dari Rp. 39.956.072.615,00 pada tahun 2015 menjadi Rp. 231.560.960.648,00 di tahun 2018.

Berdasarkan hal tersebut, penelitian bertujuan untuk mengetahui dan menganalisis pengaruh dan perkembangan pajak daerah, retribusi daerah, belanja daerah, dan pertumbuhan ekonomi Provinsi jambi selama periode tahun 2002 - 2018.

\section{METODE}

Data yang digunakan adalah data sekunder periode waktu 2002-2018. Adapun data yang digunakan mencakup realisasi Penerimaan Pajak Daerah Provinsi Jambi, Pertumbuhan Ekonomi Provinsi Jambi berdasarkan PDRB atas dasar harga konstan tahun 2010, realisasi Belanja Daerah Provinsi Jambi dan realisasi Penerimaan Retribusi Daerah Provinsi Jambi.

Data yang digunakan dalam penelitian ini berasal dari :

1. Badan Pusat Statistik (BPS) Provinsi Jambi.

2. Dinas Pendapatan, Pengelolaan Keuangan dan Aset Daerah (DPPKAD) Provinsi Jambi.

\section{Analisis deskriptif}

Metode ini digunakan untuk menjawab tujuan penelitian yang pertama yaitu perkembangan pajak daerah, retribusi daerah, belanja daerah dan pertumbuhan ekonomi yang dilihat dari nilai PDRB Provinsi Jambi selama periode tahun 2002-2018 menggunakan rumus perkembangan sebagai berikut : (Mahmudi,2016).

$$
\operatorname{PPAD}_{t}=\frac{\mathrm{PAD}_{\mathrm{t}}-\mathrm{PAD}_{\mathrm{t}-1}}{\mathrm{PAD}_{\mathrm{t}-1}} \times 100 \%
$$

Keterangan :

$\mathrm{PPAD}_{\mathrm{t}}=$ Perkembangan PAD tahun tertentu.

PAD $_{\mathrm{t}}=$ Penerimaan PAD tahun tertentu.

$\mathrm{PAD}_{\mathrm{t}-1}=$ Penerimaan PAD tahun sebelumnya

\section{Analisis kuantitatif}

Untuk menjawab tujuan kedua, yaitu pengaruh pajak daerah dan retribusi daerah terhadap belanja daerah di Provinsi Jambi selama periode tahun 2002-2018 digunakan model persamaan regresi berganda double logaritma dan persamaan dasarnya dapat dituliskan sebagai berikut : (Sunyoto, 2015)

\section{$\log Y=\beta_{0}+\beta_{1} \log X_{1}+\beta_{2} \log X_{2}+e$}

Persamaan regresi diatas, digunakan dengan bentuk persamaan regresi bergandanya sebagai berikut :

$\operatorname{LogBD}=\beta_{0}+\beta_{1} \operatorname{LogPD}_{2}+\beta_{2} \operatorname{LogRD} D_{2}+e$ 
Keterangan :

$\mathrm{BD}=$ Belanja daerah

PD = Pajak daerah

$\mathrm{RD} \quad=$ Retribusi daerah

$\beta_{0} \quad=$ Nilai konstanta

$\beta_{1}, \beta_{2}=$ Nilai koefisien regresi pajak daerah dan retribusi daerah

$\mathrm{e} \quad=$ Tingkat kesalahan/standar error

Untuk menjawab tujuan ketiga, yaitu pengaruh pajak daerah dan retribusi daerah terhadap pertumbuhan ekonomi di Provinsi Jambi selama periode tahun 2002-2018 digunakan model persamaan regresi berganda semi logaritma dan persamaan dasarnya dapat dituliskan sebagai berikut : (Sunyoto, 2015)

\section{$Y=\beta_{0}+\beta_{1} \log X_{1}+\beta_{2} \log X_{2}+e$}

Persamaan regresi diatas, digunakan dengan bentuk persamaan regresi bergandanya sebagai berikut :

$P E=\beta_{0}+\beta_{1} \operatorname{LogPD}+\beta_{2} \operatorname{LogRD} 2+e$

Keterangan :

$\mathrm{PE} \quad=$ Pertumbuhan ekonomi

PD = Pajak daerah

$\mathrm{RD}=$ Retribusi daerah

$\beta_{0} \quad=$ Nilai konstanta

$\beta_{1}, \beta_{2}=$ Nilai koefisien regresi pajak daerah dan retribusi daerah

$\mathrm{e} \quad=$ Tingkat kesalahan/standar error

\section{Uji asumsi klasik}

\section{Uji multikolinearitas}

Uji multikolinearitas digunakan untuk mengetahui ada tidaknya hubungan yang signifikan diantara variabel bebas dengan melakukan regresi suatu variabel independen terhadap variabel-variabel independen yanng lain dalam model. Apabila hasil regresi menunjukkan adanya nilai $\mathrm{R}^{2}$ yang lebih rendah dari $\mathrm{R}^{2}$ model utama, maka dapat disimpulkan tidak terjadi multikolinearitas antar variabel independen.

\section{Uji autokorelasi}

Autokorelasi digunakan untuk mengetahui apakah didalam model yang digunakan terdapat autokorelasi di antara variabel-variabel yang di amati dengan menggunakan metode Breusch-Godfrey atau LM (Lagrange Multiplier) test. Selain menggunakan LM Test, dapat juga menggunakan Durbin Watson (DW). Dalam pengertian lain autokorelasi bertujuan untuk mendeteksi apakah variabel penggangu pada suatu periode berkorelasi atau tidak berkorelasi dengan variabel pengganggu lainnya. Konsekuensi dari adanya autokorelasi pada model ialah bahwa penaksir tidak efisien dan uji t serta uji f yang biasa tidak valid walaupun hasil estimasi tidak bias. (Wahyu, 2009). 


\section{Uji heteroskedastisitas}

Uji heteroskedastisitas dalam penelitian ini menggunakan metode White's Heterocedasricity Test. Untuk mendeteksi ada tidaknya heteroskedastisitas dengan membandingkan nilai obs*R-square dan tabel $X^{2}$. Jika nilai obs*R-squared $>X^{2}$ tabel. Maka tidak lolos uji heteroskedastisitas, dan sebaliknya jika nilai obs*R-squared $<\mathrm{X}^{2}$ tabel, maka lolos uji heteroskedastisitas.

\section{Uji normalitas}

Pendugaan persamaan dengan menggunakan metode OLS yaitu data (residual) yang dibentuk model regresi linier terdistribusi normal, bukan variabel bebas ataupun variabel terikatnya. Salah satu metode yang digunakan untuk menguji normalitas adalah JB (JarqueBera Test. Apabila probabilita JB hitung lebih besar dari $5 \%$ maka residual terdistribusi normal dan sebaliknya, apabila nilainya lebih kecil tidak cukup bukti untuk menyatakan bahwa residual terdistribusi normal.

\section{Uji hipotesis}

\section{Koefisien determinasi $\left(\mathbf{R}^{2}\right)$}

Koefisien determinasi $\left(\mathrm{R}^{2}\right)$ digunakan untuk mengetahui sampai sejauh mana ketepatan atau kecocookan garis regresi yang terbentuk dalam mewakili kelompok data hasil observasi. $\mathrm{R}^{2}$ menggambarkan bagian dari variasi total yang dapat diterangkan oleh model. (Ghozali, 2013). Semakin besar nilai $\mathrm{R}^{2}$ (mendekati 1), maka ketepatannya dikatakan semakin baik. Adapun rumus untuk menentukan nilai koefisien determinasi dapat dilakukan dengan cara:

$R^{2}=\frac{\mathrm{ESS}}{\mathrm{TSS}}$

Dimana:

$\mathrm{ESS}=$ Explaind sum of square

TSS $=$ Total sum of square

\section{Parameter koefisien F (over all)}

Ghozali (2013) menjelaskan, uji F statistik digunakan untuk menunjukkan pengaruh tingkat signifikan variabel independen (bebas) yang ada dalam model secara bersama-sama (simultan) terhadap variabel dependen (tidak bebas). Adapun hipotesisnya adalah sebagai berikut :

$\mathrm{H}_{0}: \mathrm{b}_{1}, \mathrm{~b}_{2}=0$, artinya secara serentak variabel bebas tidak mempunyai pengaruh yang signifikan terhadap variabel tidak bebas.

$\mathrm{H}_{1}: \mathrm{b}_{1}, \mathrm{~b}_{2} \neq 0$, artinya secara serentak variabel bebas mempunyai pengaruh yang signifikan terhadap variabel tidak bebas.

Kriteria dalam pengambilan keputusan atas variabel yang diukur adalah:

$\mathrm{H}_{0}$ diterima, jika $\mathrm{F}$ statistik $<\mathrm{F}$ tabel

$\mathrm{H}_{1}$ diterima, jika $\mathrm{F}$ statistik $>\mathrm{F}$ tabel 
Untuk mengetahui berapa besar nilai $\mathrm{F}$ hitung dapat ditentukan dengan menggunakan cara :

$F_{\text {hitung }}=\frac{R^{2} /(k-1)}{1-R^{2} /(n-k)}$

Dimana :

$\mathrm{R}^{2}=$ Koefisien determinasi

$\mathrm{k}$ = Banyaknya variabel bebas

$\mathrm{n}$ = Banyaknya sampel/data

\section{Parameter koefisien t (parsial)}

Uji t statistik digunakan untuk mengetahui pengaruh signifikansi masing-masing variabel independen (bebas) terhadap variabel dependen (tidak bebas) dengan menganggap variabel independen lainnya konstan. (Ghozali, 2013). Dalam uji t ini digunakan hipotesis sebagai berikut:

Ho : bi $=0$, artinya tidak ada pengaruh yang signifikan antara masing-masing variabel bebas (independen) dengan variabel tidak bebas (dependen).

Ha : bi $\neq 0$, artinya ada pengaruh yang signifikan antara masing-masing variabel bebas (independen) dengan variabel tidak bebas (dependen).

Selanjutnya dilakukan pengujian dengan cara membandingkan nilai $\mathrm{t}$ statistik terhadap nilai t tabel.

Kriteria pengambilan keputusan :

$\mathrm{H}_{0}$ diterima, jika t statistik $<\mathrm{t}$ tabel

$\mathrm{H}_{1}$ diterima, jika t statistik $>\mathrm{t}$ tabel

Adapun nilai t hitung dapat diketahui dengan menggunakan cara:

$t_{\text {hitung }}=\frac{b_{i}}{S e(b i)}$

Dimana :

bi $\quad=$ Koefisien regresi parsial

$\mathrm{Se}(\mathrm{bi})=$ Standar deviasi koefisien

\section{HASIL DAN PEMBAHASAN}

\section{Perkembangan pajak daerah}

Implementasi UU No. 32 tahun 2004 mengakibatkan pemerintah daerah mempunyai kewenangan untuk menyusun berbagai kebijakan dalam pelaksanaan pembangunan daerah. Kebijakan tersebut dimaksudkan untuk mengembangkan dan memberdayakan potensi yang ada untuk dapat dijadikan sebagai sumber penerimaan daerah dan nantinya digunakan sebagai pembiayaan dalam proses pembangunan. Sumber-sumber penerimaan daerah yang digali salah satunya berasal dari penerimaan pajak daerah. Penerimaan pajak daerah sebagai salah satu pemberi kontribusi bagi penerimaan daerah, termasuk Provinsi Jambi. 
Penerimaan pajak daerah Provinsi Jambi selama tahun 2002-2018 mengalami peningkatan berbeda-beda setiap tahunnya. Perbedaan besarnya penerimaan pajak tersebut disebabkan penambahan dari jenis pajak daerah yang dipungut, adanya penngkatan tariff pajak, adanya kebijakan pemutihan pajak dan pajak yang dibayarkan oleh wajib pajak tidak tepat waktu. Rata-rata penerimaan pajak daerah Provinsi Jambi selama tahun 2002-2018 terjadi peningkatan sebesar 17,03 persen, yaitu dari Rp.123.718.257.750,05 pada tahun 2002 dan meningkat menjadi Rp.1.374.289.409.762,00 pada tahun 2018.

Tabel 1. Pajak daerah Provinsi Jambi Tahun 2002-2018

\begin{tabular}{ccc}
\hline Tahun & Penerimaan Pajak Daerah $($ Rp) & Perkembangan $(\boldsymbol{\%})$ \\
\hline 2002 & $123.718 .257 .750,05$ & - \\
2003 & $180.605 .667 .907,00$ & 45,98 \\
2004 & $246.153 .517 .603,05$ & 36,29 \\
2005 & $281.722 .332 .085,11$ & 14,45 \\
2006 & $311.238 .808 .550,00$ & 10,48 \\
2007 & $372.444 .014 .569,00$ & 19,67 \\
2008 & $527.008 .669 .551,00$ & 41,50 \\
2009 & $438.533 .680 .183,00$ & $-16,79$ \\
2010 & $602.355 .302 .089,05$ & 37,36 \\
2011 & $532.512 .574 .000,43$ & $-11,59$ \\
2012 & $808.258 .511 .161,65$ & 51,78 \\
2013 & $841.884 .751 .184,05$ & 4,16 \\
2014 & $1.010 .560 .585 .181,00$ & 20,04 \\
2015 & $1.010 .318 .979 .968,26$ & $-0,02$ \\
2016 & $966.519 .346 .830,09$ & $-4,34$ \\
2017 & $1.316 .162 .468 .028,00$ & 36,18 \\
2018 & $1.374 .289 .409 .762,00$ & 4,42 \\
\hline Rata-Rata & & $\mathbf{1 7 , 0 3}$ \\
\hline
\end{tabular}

Sumber: Dinas pendapatan, pengelolaan keuangan \& aset daerah (DPPKAD) Provinsi Jambi

\section{Perkembangan retribusi daerah}

Retribusi daerah sebagai bagian dari pendapatan asli daerah (PAD) di Provinsi Jambi selama tahun 2002-2018 juga mengalami fluktuasi, yaitu naik dan turun. Penerimaan retribusi daerah Provinsi Jambi memiliki nilai dan persentase peningkatan lebih rendah dibanding penerimaan pajak daerah. Rata-rata penerimaan retribusi daerah mengalami peningkatan setiap tahun sebesar 16,49 persen. Penerimaan retribusi daerah Provinsi Jambi tahun 2002 adalah Rp. 10.800.424.981,07 dan meningkat menjadi Rp. 20.208.219.803,00 pada tahun 2018 . 
Tabel 2. Retribusi daerah Provinsi Jambi Tahun 2002 - 2018

\begin{tabular}{ccc}
\hline Tahun & Penerimaan retribusi daerah $(\mathbf{R p )}$ & Perkembangan $(\%)$ \\
\hline 2002 & $10.800 .424 .981,07$ & - \\
2003 & $23.529 .681 .040,00$ & 117,86 \\
2004 & $16.266 .665 .697,07$ & $-30,87$ \\
2005 & $17.332 .879 .987,00$ & 6,55 \\
2006 & $20.336 .902 .908,00$ & 17,33 \\
2007 & $23.195 .023 .572,00$ & 14,05 \\
2008 & $51.489 .563 .913,00$ & 121,99 \\
2009 & $36.852 .013 .379,17$ & $-28,43$ \\
2010 & $43.609 .630 .065,22$ & 18,34 \\
2011 & $7.462 .787 .500,17$ & $-82,89$ \\
2012 & $13.405 .305 .831,16$ & 79,63 \\
2013 & $15.363 .758 .638,03$ & 14,61 \\
2014 & $14.587 .180 .553,00$ & $-5,05$ \\
2015 & 19.336 .663 .877 .00 & 32,56 \\
2016 & $18.684 .766 .040,11$ & $-3,37$ \\
2017 & $19.864 .952 .486,03$ & 6,32 \\
2018 & $20.208 .219 .803,00$ & 1,73 \\
\hline Rata-Rata & & $\mathbf{1 6 , 4 9}$ \\
Sumber: Dinas pendapatan, pengelolaan keuangan \& aset daerah (DPPKAD) Provinsi Jambi
\end{tabular}

\section{Perkembangan belanja daerah}

Pembangunan yang dilaksanakan harus didukung dengan ketersediaan dana sebagai sumber pembiayaannya. Dana yang tersedia sebagai sumber pembiayaan pembangunan semakin besar, maka akan semakin besar kegiatan yang dapat dilaksanakan. Sumber pembiayaan pembangunan yang dikeluarkan digunakan untuk membiayai kegiatan atau program yang dilaksanakan di Provinsi Jambi dalam upaya meningkatkan pelayanan pada masyarakat.

Tabel 3. Belanja daerah Provinsi Jambi Tahun $2002-2018$

\begin{tabular}{ccc}
\hline Tahun & Belanja Daerah (rupiah) & Perkembangan (\%) \\
\hline 2002 & $415.162 .017 .264,16$ & - \\
2003 & $489.371 .648 .110,72$ & 17,87 \\
2004 & $654.977 .310 .888,71$ & 33,84 \\
2005 & $776.834 .624 .188,50$ & 18,6 \\
2006 & $1.156 .842 .788 .315,54$ & 48,92 \\
2007 & $1.343 .592 .116 .690,52$ & 16,14 \\
2008 & $1.615 .956 .992 .043,04$ & 20,27 \\
2009 & $1.670 .048 .305 .683,00$ & 3,35 \\
2010 & $1.488 .130 .349 .597,62$ & $-10,89$ \\
2011 & $1.750 .241 .856 .160,33$ & 17,61 \\
2012 & $2.259 .162 .243 .597,75$ & 29,08 \\
2013 & $2.795 .338 .812 .275,40$ & 23,73 \\
2014 & $2.603 .725 .690 .254,82$ & $-6,85$ \\
2015 & $3.425 .751 .341 .965,03$ & 31,57 \\
2016 & $3.694 .484 .968 .673,11$ & 7,85 \\
2017 & $4.342 .308 .805 .704,06$ & 17,54 \\
2018 & $4.515 .143 .629 .159,00$ & 3,98 \\
\hline Rata-Rata & & $\mathbf{1 6 , 0 4}$ \\
Sumber: Dinas pendapatan, pengelolaan keuangan \& aset daerah (DPPKAD) Provinsi Jambi
\end{tabular}


Perkembangan belanja daerah Provinsi Jambi selama Tahun 2002-2018 bersifat berfluktuatif, dimana rata-rata mengalami peningkatan setiap tahun sebesar 16,04 persen. Belanja daerah meningkat dari berjumlah Rp.415.162.017.264,16 pada Tahun 2002 naik menjadi Rp.4.515.143.629.159,00 di Tahun 2018.

\section{Perkembangan PDRB}

Meningkatnya PDRB akan mempengaruhi peningkatan pendapatan perkapita dari masyarakat dan yang lain-lainnya. Hal ini sejalan dengan pendapat Kuncoro (2013), peningkatan PDRB, selain akan memberi dampak pada peningkatan kesejahteraan masyarakat melalui peningkatan pendapatan perkapita juga dapat membawa dampak pada terciptanya kesempatan kerja yang luas, pengurangan jumlah pengangguran, mengurangi jumlah penduduk miskin dan sebagainya. PDRB yang meningkat dapat dilihat dari pertumbuhan yang terjadi setiap tahunnya.

Pertumbuhan ekonomi Provinsi Jambi yang diukur dari peningkatan nilai PDRB atas dasar harga konstan tahun 2010 dalam satuan juta rupiah selama tahun 2002-2018, rata-rata tumbuh sebesar 5,76 persen setiap tahun. Nilai PDRB pada tahun 2002 adalah Rp. 56.039,58 dan naik menjadi Rp. 142.968,30 pada tahun 2018. Pertumbuhan ekonomi tertinggi terjadi pada tahun 2011 yaitu tumbuh sebesar 8,54 persen dengan nilai RP. 97.740,87 dan terendah mengalami pertumbuhan terjadi pada tahun 2015 yaitu sebesar 4,21 persen dengan nilai PDRB sebesar Rp. 125.037,40.

Tabel 4. PDRB atas dasar harga Konstan Tahun 2010 Provinsi Jambi Tahun 2002-2018

\begin{tabular}{ccc}
\hline Tahun & Nilai PDRB (juta rupiah) & Perkembangan $(\boldsymbol{\%})$ \\
\hline 2002 & $56.039,58$ & - \\
2003 & $58.842,43$ & 5 \\
2004 & $62.007,09$ & 5,38 \\
2005 & $65.459,96$ & 5,57 \\
2006 & $69.313,16$ & 5,89 \\
2007 & $74.039,64$ & 6,82 \\
2008 & $79.343,22$ & 7,16 \\
2009 & $84.415,12$ & 6,39 \\
2010 & $90.618,41$ & 7,35 \\
2011 & $97.740,87$ & 8,54 \\
2012 & $104.615,08$ & 7,03 \\
2013 & $111.766,13$ & 7,07 \\
2014 & $119.991,44$ & 7,76 \\
2015 & $125.037,40$ & 4,21 \\
2016 & $130.501,13$ & 4,37 \\
2017 & $136.501,71$ & 4,6 \\
2018 & $142.968,30$ & 4,74 \\
\hline
\end{tabular}

Sumber: BPS Provinsi Jambi, 2020

Pengaruh pajak daerah dan retribusi daerah terhadap belanja daerah provinsi jambi selama periode Tahun 2002-2018

Berdasarkan hasil perhitungan dengan menggunakan pengaruh pajak daerah dan retribusi daerah terhadap belanja daerah Provinsi Jambi selama periode tahun 2002-2018 ditunjukkan pada Tabel 5. sebagai berikut : 
Tabel 5. Hasil perhitungan pengaruh pajak daerah dan retribusi daerah terhadap belanja daerah Provinsi Jambi Selama Tahun 2002-2018

\begin{tabular}{lrlrr}
\hline \hline \multicolumn{1}{c}{ Variable } & Coefficient & \multicolumn{1}{c}{ Std. Error } & t-Statistic & Prob. \\
\hline \multicolumn{1}{c}{ C } & 1.729418 & 1.403883 & 0.586529 & 0.5669 \\
$\quad$ Pajak Daerah01 & 0.813313 & 0.233628 & 3.481231 & 0.0417 \\
Retribusi Daerah01 & 0.631165 & 0.140924 & 4.478762 & 0.0237 \\
\hline \hline & 0.921501 & Mean dependent var & 3.332941 \\
R-squared & 0.908412 & S.D. dependent var & 0.562325 \\
Adjusted R-squared & 0.533939 & Akaike info criterion & 1.741714 \\
S.E. of regression & 3.991268 & Schwarz criterion & 1.888752 \\
Sum squared resid & -11.80457 & Hannan-Quinn criter. & 1.756330 \\
Log likelihood & 6.873237 & Durbin-Watson stat & 2.169845 \\
F-statistic & 0.001057 & & \\
Prob(F-statistic) & \multicolumn{3}{l}{} \\
\hline \hline
\end{tabular}

Sumber: Data diolah, 2020

Hasil perhitungan dengan program Eviews 12.0 diatas, selanjutnya dapat ditulis bentuk persamaan regresi bergandanya sebagai berikut:

$\operatorname{LogBD}=1,729418+0,813313 \log P D+0,631165 \operatorname{LogRD}$

\section{Uji asumsi klasik}

\section{Uji normalitas}

Uji normalitas dilakukan bertujuan untuk mengetahui apakah data berdistribusi normal atau tidak. Hasil uji normalitas, diperoleh nilai Probabilitas Jarque-Bera sebesar 0,687059 dan Nilai Probabilitas Jarque-Bera 0,687059 > 0,05 ( $\alpha=5 \%)$ yang digunakan. Artinya model memiliki residual yang terdistribusi normal dan asumsi klasik tentang kenormalan telah dipenuhi, sehingga model memenuhi syarat uji asumsi klasik. Hasil uji normalitas adalah :

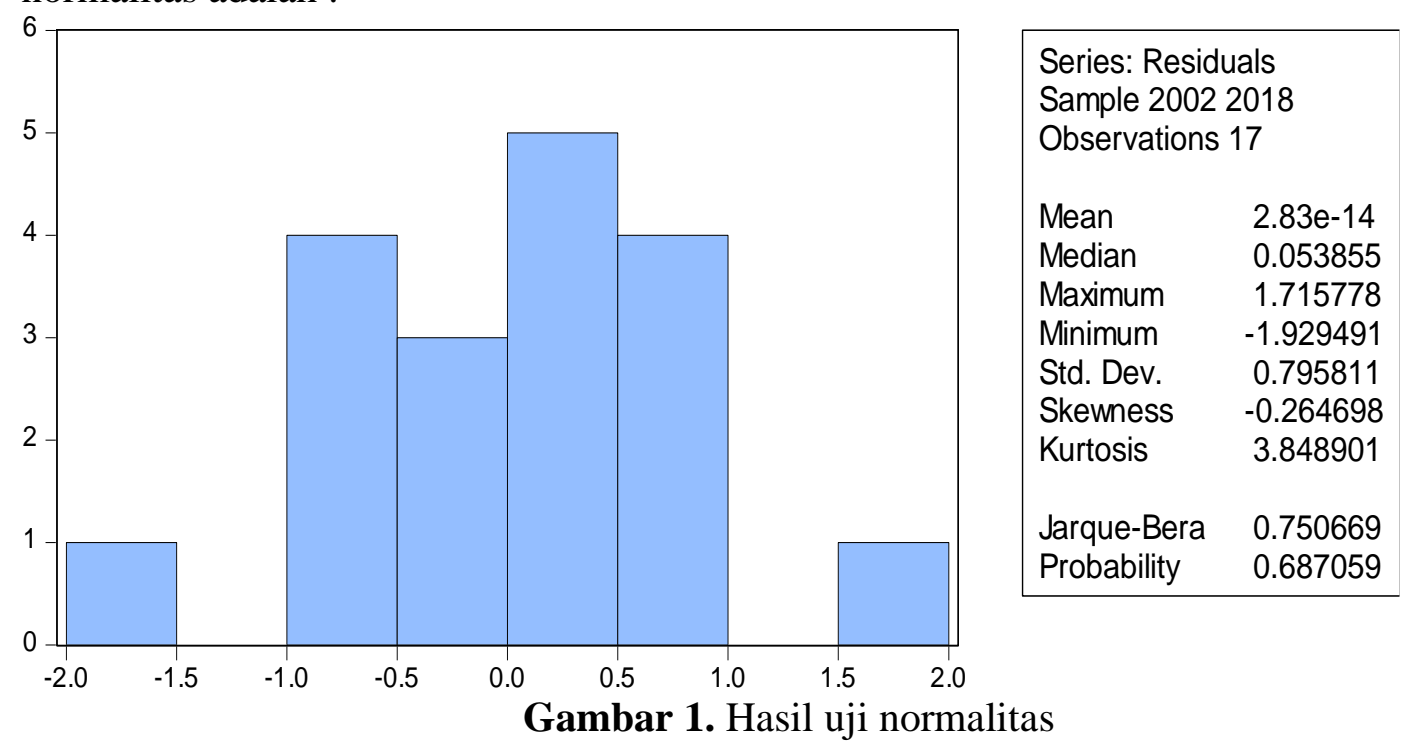




\section{Uji multikolinearitas}

Uji multikolinearitas dilakukan untuk menguji apakah pada model regresi ditemukan adanya korelasi antar variabel independen. Uji multikolinearitas pada penelitian ini menggunakan Inflation Variance Factor (VIF). Jika nilai VIF melebihi angka 10 maka terdapat multikolinearitas. (Wahyu, 2009).

Tabel 6. Hasil perhitungan uji multikolinieritas pengaruh pajak daerah dan retribusi daerah terhadap belanja daerah Provinsi Jambi Selama Tahun 2002-2018

\begin{tabular}{cccc}
\hline \hline Variable & $\begin{array}{c}\text { Coefficient } \\
\text { Variance }\end{array}$ & $\begin{array}{c}\text { Uncentered } \\
\text { VIF }\end{array}$ & $\begin{array}{c}\text { Centered } \\
\text { VIF }\end{array}$ \\
\hline \hline C & 1.970888 & 94.05214 & NA \\
Pajak Daerah01 & 0.188033 & 80.81136 & 2.063124 \\
Retribusi Daerah01 & 0.410783 & 43.69072 & 3.205147 \\
\hline \hline
\end{tabular}

Sumber: Data diolah, 2020

Berdasarkan hasil perhitungan Inflation Variance Factor (VIF) diperoleh nilai VIF dari Centered VIF untuk kedua variabel, yaitu : pajak daerah $=2,063124<10$ dan retribusi daerah $=3,205147<10$. Atinya, pajak daerah dan retribusi daerah (variabel independen) terbebas dari multikolinearitas atau pada model regresi tidak ditemukan korelasi antar variabel independen dan model telah memenuhi syarat uji asumsi klasik.

\section{Uji autokorelasi}

Uji autokorelasi dilakukan untuk mengetahui apakah dalam model regresi linear ada korelasi antara kesalahan pengganggu pada periode $t$ (sebelumnya) atau residual (kesalahan pengganggu) tidak bebas dari satu observasi ke observasi lainnya. Hasil hasil uji autokorelasi dengan uji Breusch-Godfrey Serial Correlation LM Test diperoleh nilai Prob Chi-Square (2) sebesar 0,7789, dimana nilai Prob Chi-Square (2) lebih besar dari tingkat alpha 0,05 $(\alpha=5$ $\%$ ) atau 0,7789 > 0,05. Artinya, pada model regresi tidak terjadi autokorelasi, sehingga model regresi memenuhi syarat uji asumsi klasik.

Tabel 7. Hasil perhitungan uji autokorelasi pengaruh pajak daerah dan retribusi daerah terhadap belanja daerah Provinsi Jambi Selama Tahun 2002-2018

\begin{tabular}{llll}
\hline \hline F-statistic & 0.181724 & Prob. F(2,12) & 0.8361 \\
Obs*R-squared & 0.499748 & Prob. Chi-Square(2) & 0.7789 \\
\hline \hline
\end{tabular}

$\overline{\text { Sumber: Data diolah }}, \overline{\overline{2020}}$

\section{Uji heteroskedastisitas}

Uji heterokedastisitas bertujuan untuk mengetahui apakah dalam model, residual memiliki varians yang konstan atau tidak. Berdasarkan hasil perhitungan uji heterokedastisitas White, diperoleh nilai Prob Chi-Square sebesar 0,7235. Pada saat nilai Prob Chi-Square lebih besar dari tingkat alpha $0,05(\alpha=5 \%)$ atau $0,7235>0,05$. Artinya, pada model regresi tidak terjadi heteroskedastisitas, sehingga model regresi memenuhi syarat uji asumsi klasik. 
Tabel 8. Hasil perhitungan uji heteroskedastisitas pengaruh pajak daerah dan retribusi daerah terhadap belanja daerah Provinsi Jambi Selama Tahun 2002-2018

\begin{tabular}{llll}
\hline \hline F-statistic & 0.442563 & Prob. F(5,11) & 0.8101 \\
Obs*R-squared & 2.847073 & Prob. Chi-Square(5) & 0.7235 \\
Scaled explained SS & 12.47491 & Prob. Chi-Square(5) & 0.5288 \\
\hline \hline
\end{tabular}

Sumber: Data diolah, 2020

\section{Pengujian hipotesis}

\section{Koefisien determinasi $\left(\mathbf{R}^{2}\right)$}

Besarnya pengaruh variabel pajak daerah dan retribusi daerah dalam menjelaskan terjadinya perubahan pada variabel dependen yaitu belanja daerah di Provinsi Jambi selama tahun 2002-2018 dapat diketahui dari nilai koefisien determinasi, yaitu nilai R-squared. Adapun nilai R-squared diperoleh sebesar 0,921501. Artinya, variabel pajak daerah (PD) dan retribusi daerah (RD) mampu menjelaskan perubahan pada variabel belanja daerah (BD) sebesar 0,921501 atau 92,15 persen, sedangkan sisanya sebesar 0,078499 atau 7,85 persen dijelaskan oleh variabel-variabel lain diluar variabel independen yang digunakan dalam penelitian ini.

\section{Parameter koefisien F (over all)}

Uji F statistik digunakan untuk melihat berapa besar pengaruh variabel independen terhadap variabel dependen secara bersama-sama, yaitu dengan membandingkan nilai Fhitung terhadap nilai F-tabel. Berdasarkan hasil perhitung diperoleh nilai F-hitung sebesar 6,873237 dan nilai F-tabel pada df $(2,12)$ dengan tingkat alpa yang di gunakan 0,05 adalah sebesar 3,89, maka F-hitung =6,873237 > F-tabel = 3,89. Artinya, secara bersama-sama variabel pajak daerah dan retribusi daerah berpengaruh terhadap belanja daerah Provinsi Jambi selama periode tahun 2002-2018. Tingkat probabilita F-statistik sebesar 0,001057 dan lebih kecil dari alpa $(\alpha)$ 0,05, yang menunjukkan terdapat pengaruh yang signifikan variabel pajak daerah dan retribusi daerah berpengaruh terhadap belanja daerah Provinsi Jambi selama periode tahun 2002-2018.

\section{Parameter koefisien $\mathbf{t}$ (parsial)}

Uji t statistik digunakan untuk mengukur pengaruh variabel independen (variabel bebas) satu persatu terhadap variabel dependen (tidak bebas). Adapun hasil pengujiannya adalah :

\section{Pengaruh pajak daerah terhadap belanja daerah}

Berdasarkan hasil regresi diperoleh nilai koefisien regresi pajak daerah adalah positif sebesar 0,813313, nilai t-hitung sebesar 3,481231 dan tingkat signifikansi (prob) sebesar 0,0417. Pada saat df (degree of freedom) $=16$ dan alpa $(\alpha)=0,05$ menggunakan uji dua arah diperoleh nilai t-tabel sebesar 2,120, maka t-hitung $=3,481231>$ t-tabel $=2,120$ dan nilai signifikansi (prob) $0,0138<0,05$, maka hipotesis nol (Ho) ditolak dan menerima hipotesis alternatif (Ha) . Artinya variabel pajak daerah secara parsial (individu) berpengaruh positif dan signifikan terhadap belanja daerah di Provinsi Jambi.

\section{Pengaruh retribusi daerah terhadap belanja daerah}

Berdasarkan hasil regresi diperoleh nilai koefisien regresi retribusi daerah adalah positif sebesar 0,631165, nilai t-hitung sebesar 4,478762 dan tingkat signifikansi (prob) 
sebesar 0,0237. Pada saat df (degree of freedom) $=16$ dan $\alpha=0,05$ menggunakan uji dua arah diperoleh nilai t-tabel sebesar 2,120, maka t-hitung $=4,478762>$ t-tabel $=2,120$ dan nilai signifikansi (prob) $0,0237<0,05$, maka hipotesis nol (Ho) ditolak dan menerima hipotesis alternatif (Ha) . Artinya variabel retribusi daerah secara parsial (individu) berpengaruh positif dan signifikan terhadap belanja daerah di Provinsi Jambi.

Berdasarkan hasil uji asumsi klasik dan uji hipotesis dalam penelitian ini, maka model regresi yang digunakan telah memenuhi persyaratan dan terbebas dari uji asumsi klasik. Berdasarkan hasil perhitungan regresi linear berganda diatas, maka nilai konstanta dan nilai koefisien regresi dapat di interpretasi: 1).Nilai konstanta sebesar 1,729418, artinya jika variabel bebas (variabel independen) yaitu pajak daerah dan retribusi daerah dianggap konstan (tetap) atau sama dengan nol, maka belanja daerah di Provinsi Jambi ada sebesar 1,729418 persen. Belanja daerah di Provinsi Jambi terjadi disebabkan ada pengaruh variabel lain di luar pajak daerah dan retribusi daerah. 2).Koefisien regresi pajak daerah adalah 0,813313 dengan tingkat siginifikansi (prob) sebesar 0,0417. Artinya, pajak daerah berpengaruh postif terhadap belanja daerah di Provinsi Jambi sebesar 0,813313 dan signifikan, dimana prob $=0,0417<0,05$. Jika pajak daerah naik sebesar 1 persen, maka belanja daerah di Provinsi Jambi akan naik sebesar 0,461317 persen. 2).Koefisien regresi retribusi daerah adalah 0,631165 dengan tingkat signifikansi (prob) sebesar 0,0237. Artinya, retribusi daerah berpengaruh postif terhadap belanja daerah di Provinsi Jambi sebesar 0,631165 dan signifikan, dimana prob $=0,0237<0,05$. Jika retribusi daerah naik sebesar 1 persen, maka belanja daerah di Provinsi Jambi akan naik sebesar 0,631165 persen.

\section{Pengaruh pajak daerah dan retribusi daerah terhadap pertumbuhan ekonomi Provinsi Jambi Selama Periode Tahun 2002-2018}

Berdasarkan hasil perhitungan pengaruh pajak daerah dan retribusi daerah terhadap pertumbuhan ekonomi Provinsi Jambi selama periode tahun 2002-2018 ditunjukkan pada Tabel 9 dibawah. Hasil perhitungan dengan program Eviews 12.0, selanjutnya dapat ditulis bentuk persamaan regresi bergandanya sebagai berikut :

$\mathrm{PE}=7,271625+0,461317 \operatorname{LogPD}+1,686495 \operatorname{LogRD}$

Tabel 9. Hasil perhitungan pengaruh pajak daerah dan retribusi daerah terhadap pertumbuhan ekonomi Provinsi Jambi Selama Tahun 2002-2018

\begin{tabular}{lrlrr}
\hline \hline \multicolumn{1}{c}{ Variable } & Coefficient & \multicolumn{1}{c}{ Std. Error } & t-Statistic & Prob. \\
\hline \multicolumn{1}{c}{ C } & 7.271625 & 3.603277 & 2.018059 & 0.0632 \\
$\quad$ Pajak Daerah01 & 0.461317 & 0.112971 & 4.083499 & 0.0138 \\
Retribusi Daerah01 & 1.686495 & 0.345027 & 4.888009 & 0.0268 \\
\hline \hline & 0.930755 & Mean dependent var & 6.102353 \\
R-squared & 0.910566 & S.D. dependent var & 1.288873 \\
Adjusted R-squared & 1.370434 & Akaike info criterion & 3.626917 \\
S.E. of regression & 26.29325 & Schwarz criterion & 3.773955 \\
Sum squared resid & -27.82880 & Hannan-Quinn criter. & 3.641533 \\
Log likelihood & 6.076102 & Durbin-Watson stat & 0.711197 \\
F-statistic & 0.007102 & & \\
Prob(F-statistic) & \multicolumn{3}{l}{} & \\
\hline \hline
\end{tabular}

Sumber: Data diolah, 2020 


\section{Uji asumsi klasik}

\section{Uji normalitas}

Uji normalitas dilakukan bertujuan untuk mengetahui apakah data berdistribusi normal atau tidak. Berdasarkan hasil uji normalitas yang dilakukan dalam penelitian ini, diperoleh nilai Probabilitas Jarque-Bera sebesar 0,534499. Nilai Probabilitas Jarque-Bera selanjutnya di bandingkan dengan nilai alpa yang digunakan dan nilainya 0,534499>0,05 $(\alpha=5 \%)$ yang digunakan. Artinya model memiliki residual yang terdistribusi normal dan asumsi klasik tentang kenormalan telah dipenuhi, sehingga model memenuhi syarat uji asumsi klasik. Hasil uji normalitas adalah :

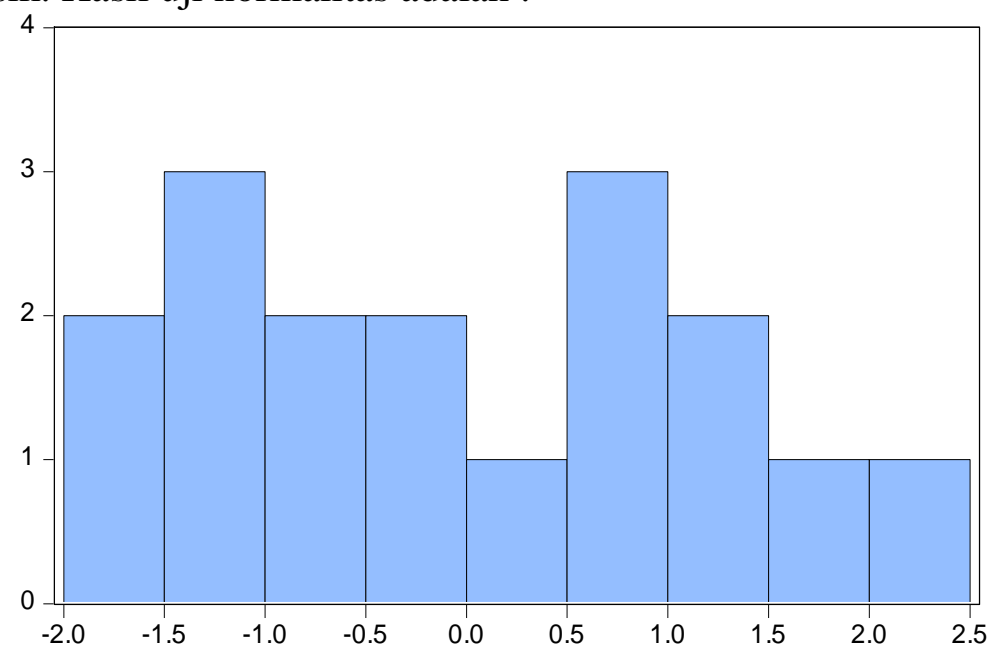

\begin{tabular}{|lr|}
\hline \multicolumn{2}{|l|}{ Series: Residuals } \\
Sample 2002 2018 \\
Observations 17 \\
Mean & $-1.04 \mathrm{e}-16$ \\
Median & -0.236539 \\
Maximum & 2.191719 \\
Minimum & -1.851097 \\
Std. Dev. & 1.281924 \\
Skewness & 0.102717 \\
Kurtosis & 1.686027 \\
& \\
Jarque-Bera & 1.252849 \\
Probability & 0.534499 \\
\hline
\end{tabular}

Gambar 2. Uji normalitas

\section{Uji multikolinearitas}

Uji multikolinearitas dilakukan untuk menguji apakah pada model regresi ditemukan adanya korelasi antar variabel independen. Uji multikolinearitas pada penelitian ini menggunakan Inflation Variance Factor (VIF). Jika nilai VIF melebihi angka 10 maka terdapat multikolinearitas. (Wahyu, 2009)

Tabel 10. Hasil perhitungan uji multikolinieritas pengaruh pajak daerah dan retribusi daerah terhadap pertumbuhan ekonomi Provinsi Jambi Tahun 2002-2018

\begin{tabular}{cccc}
\hline \hline Variable & $\begin{array}{c}\text { Coefficient } \\
\text { variance }\end{array}$ & $\begin{array}{c}\text { Uncentered } \\
\text { VIF }\end{array}$ & $\begin{array}{c}\text { Centered } \\
\text { VIF }\end{array}$ \\
\hline \hline C & 12.98361 & 117.5244 & NA \\
Pajak daerah01 & 1.238704 & 83.85037 & 1.003874 \\
Retribusi daerah01 & 2.706113 & 41.91495 & 1.003874 \\
\hline \hline
\end{tabular}

Sumber: Data diolah, 2020

Berdasarkan hasil perhitungan Inflation Variance Factor (VIF) diperoleh nilai VIF dari Centered VIF untuk kedua variabel, yaitu : pajak daerah dan retribusi daerah $=1,003874$, maka nilai VIF untuk kedua variabel bebas (variabel independen) adalah 1,003874< 10 . Atinya, pajak daerah dan retribusi daerah (variabel independen) terbebas dari 
multikolinearitas atau pada model regresi tidak ditemukan korelasi antar variabel independen dan model telah memenuhi syarat uji asumsi klasik.

\section{Uji autokorelasi}

Uji autokorelasi dilakukan untuk mengetahui apakah dalam model regresi linear ada korelasi antara kesalahan pengganggu pada periode $t$ (sebelumnya) atau residual (kesalahan pengganggu) tidak bebas dari satu observasi ke observasi lainnya. Uji autokorelasi yang digunakan adalah menggunakan uji Breusch-Godfrey Serial Correlation LM Test dengan membandingkan nilai Prob. Obs*R-squared terhadap tingkat alpha yang digunakan, yaitu $0,05(\alpha=5 \%)$. Nilai Prob. Obs*R-squared $>$ tingkat alpha $0,05(\alpha=5 \%)$, maka tidak terjadi autokorelasi dan nilai Prob. Obs*R-squared < tingkat alpha 0,05 ( $\alpha=5 \%)$, maka terjadi autokorelasi.

Tabel 11. Hasil perhitungan uji autokorelasi pengaruh pajak daerah dan retribusi daerah terhadap pertumbuhan ekonomi Provinsi Jambi Selama Tahun 2002-2018

\begin{tabular}{llll}
\hline \hline F-statistic & 4.018709 & Prob. F(2,12) & 0.4461 \\
Obs*R-squared & 6.819048 & Prob. Chi-Square(2) & 0.4231 \\
\hline \hline
\end{tabular}

Sumber: Data diolah, 2020

Hasil hasil uji autokorelasi dengan uji Breusch-Godfrey Serial Correlation LM Test diperoleh nilai Prob Chi-Square (2) sebesar 0,4231, dimana nilai Prob Chi-Square (2) lebih besar dari tingkat alpha $0,05(\alpha=5 \%)$ atau 0,4231 $>0,05$. Artinya, pada model regresi tidak terjadi autokorelasi, sehingga model regresi memenuhi syarat uji asumsi klasik.

\section{Uji heteroskedastisitas}

Uji heterokedastisitas bertujuan untuk mengetahui apakah dalam model, residual memiliki varians yang konstan atau tidak. Uji heteroskedastisitas dalam penelitian ini menggunakan uji heterokedasticity White, yaitu dengan membandingkan nilai probabilitas Obs*R-squared terhadap tingkat alpha yang digunakan, yaitu 0,05 $(\alpha=5 \%)$. Apabila nilai probabilitas $O b s^{*} R$-squared $>0,05$, maka tidak terjadi heteroskedastisitas dan apabila nilai probabilitas $O b s^{*} R$-squared $<0,05$, maka terjadi heteroskedastisitas.

Tabel 12. Hasil perhitungan uji heteroskedastisitas pengaruh pajak daerah dan retribusi daerah terhadap pertumbuhan ekonomi Provinsi Jambi Tahun 2002-2018

\begin{tabular}{llll} 
F-statistic & 6.338375 & Prob. F(5,11) & 0.0445 \\
Obs*R-squared & 10.24712 & Prob. Chi-Square(5) & 0.6685 \\
Scaled explained SS & 2.383808 & Prob. Chi-Square(5) & 0.7939 \\
\hline
\end{tabular}

Sumber: Data diolah, 2020

Berdasarkan hasil perhitungan uji heterokedastisitas White, diperoleh nilai Prob ChiSquare sebesar 0,6685. Pada saat nilai Prob Chi-Square lebih besar dari tingkat alpha 0,05 $(\alpha=5 \%)$ atau 0,6685 $>0,05$. Artinya, pada model regresi tidak terjadi heteroskedastisitas, sehingga model regresi memenuhi syarat uji asumsi klasik. 


\section{Pengujian hipotesis}

\section{Uji koefisien determinasi $\left(\mathbf{R}^{2}\right)$}

Besarnya pengaruh variabel pajak daerah dan retribusi daerah dalam menjelaskan terjadinya perubahan pada variabel dependen yaitu pertumbuhan ekonomi di Provinsi Jambi selama tahun 2002-2018 dapat diketahui dari nilai koefisien determinasi, yaitu nilai Rsquared. Adapun nilai R-squared diperoleh sebesar 0,930755. Artinya, variabel pajak daerah (PD) dan retribusi daerah (RD) mampu menjelaskan perubahan pada variabel pertumbuhan ekonomi (PE) sebesar 0,930755 atau 93,08 persen, sedangkan sisanya sebesar 0,069245 atau 6,92 persen dijelaskan oleh variabel-variabel lain diluar variabel independen yang digunakan dalam penelitian ini.

\section{Parameter koefisien F (over all)}

Uji $\mathrm{F}$ statistik digunakan untuk melihat berapa besar pengaruh variabel independen terhadap variabel dependen secara bersama-sama, yaitu dengan membandingkan nilai Fhitung terhadap nilai F-tabel. Berdasarkan hasil perhitung diperoleh nilai F-hitung sebesar 6,076102 dan nilai F-tabel pada df $(2,12)$ dengan tingkat alpa yang di gunakan 0,05 adalah sebesar 3,89, maka F-hitung = 6,076102 > F-tabel = 3,89. Artinya, secara bersama-sama variabel pajak daerah dan retribusi daerah berpengaruh terhadap pertumbuhan ekonomi Provinsi Jambi selama periode tahun 2002-2018. Tingkat Probabilita F-statistik sebesar 0,007102 dan lebih kecil dari alpa $(\alpha) \quad 0,05$, yang menunjukkan terdapat pengaruh yang signifikan variabel pajak daerah dan retribusi daerah berpengaruh terhadap pertumbuhan ekonomi Provinsi Jambi selama periode tahun 2002-2018.

\section{Parameter koefisien t (parsial)}

Uji t statistik digunakan untuk mengukur pengaruh variabel independen (variabel bebas) satu persatu terhadap variabel dependen (tidak bebas). Adapun hasil pengujiannya adalah :

\section{Pengaruh pajak daerah terhadap pertumbuhan ekonomi}

Berdasarkan hasil regresi diperoleh nilai koefisien regresi pajak daerah adalah positif sebesar 0,461317, nilai t-hitung sebesar 4,083499 dan tingkat signifikansi (prob) sebesar 0,0138. Pada saat df (degree of freedom) $=16$ dan alpa $(\alpha)=0,05$ menggunakan uji dua arah diperoleh nilai t-tabel sebesar 2,120, maka t-hitung $=4,083499>\mathrm{t}$-tabel $=2,120$ dan nilai signifikansi (prob) 0,0138<0,05, maka hipotesis nol (Ho) ditolak dan menerima hipotesis alternatif (Ha) artinya variabel pajak daerah secara parsial (individu) berpengaruh positif dan signifikan terhadap pertumbuhan ekonomi di Provinsi Jambi.

\section{Pengaruh retribusi daerah terhadap pertumbuhan ekonomi}

Berdasarkan hasil regresi diperoleh nilai koefisien regresi retribusi daerah adalah positif sebesar 1,686495, nilai t-hitung sebesar 4,888009 dan tingkat signifikansi (prob) sebesar 0,0268. Pada saat df (degree of freedom) $=16$ dan $\alpha=0,05$ menggunakan uji dua arah diperoleh nilai t-tabel sebesar 2,120, maka t-hitung $=4,888009>$ t-tabel $=2,120$ dan nilai signifikansi (prob) 0,0268 $<0,05$, maka hipotesis nol (Ho) ditolak dan menerima hipotesis alternatif (Ha). Artinya variabel retribusi daerah secara parsial (individu) berpengaruh positif dan signifikan terhadap pertumbuhan ekonomi di Provinsi Jambi.

Berdasarkan hasil uji asumsi klasik dan uji hipotesis dalam penelitian ini, maka model regresi yang digunakan telah memenuhi persyaratan dan terbebas dari uji asumsi klasik. Berdasarkan hasil perhitungan regresi linear berganda diatas, maka nilai konstanta dan nilai 
koefisien regresi dapat di interpretasi sebagai berikut: 1)Nilai konstanta sebesar 7,271625, artinya jika variabel bebas (variabel independen) yaitu pajak daerah dan retribusi daerah dianggap konstan (tetap) atau sama dengan nol, maka pertumbuhan ekonomi di Provinsi Jambi ada sebesar - 7,271625 persen. Pertumbuhan ekonomi di Provinsi Jambi terjadi disebabkan ada pengaruh variabel lain di luar pajak daerah dan retribusi daerah. 2).Koefisien regresi pajak daerah adalah 0,461317 dengan tingkat siginifikansi (prob) sebesar 0,0138. Artinya, pajak daerah berpengaruh postif terhadap pertumbuhan ekonomi di Provinsi Jambi sebesar 0,461317 dan signifikan, dimana prob $=0,0138<0,05$. Jika pajak daerah naik sebesar 1 persen, maka pertumbuhan ekonomi di Provinsi Jambi akan naik sebesar 0,461317 persen. 6YKoefisien regresi retribusi daerah adalah 1,686495 dengan tingkat signifikansi (prob) sebesar 0,0268. Artinya, retribusi daerah berpengaruh postif terhadap pertumbuhan ekonomi di Provinsi Jambi sebesar 1,686495 dan signifikan, dimana prob = 0,0268<0,05. Jika retribusi daerah naik sebesar 1 persen, maka pertumbuhan ekonomi di Provinsi Jambi akan naik sebesar 1,686495 persen.

\section{Implikasi kebijakan}

Pembangunan yang dilaksanakan setiap daerah, termasuk Provinsi Jambi tentu membutuhkan anggaran. Anggaran yang dibutuhkan dalam pelaksanaan pembangunan haruslah tersedia. Peningkatan anggaran pembangunan dapat dilakukan melalui upaya meningkatkan sumber penerimaan daerah. Peningkatan penerimaan pajak daerah dan retribusi daerah akan memberi dampak pada peningkatan anggaran belanja daerah.

Upaya yang dilakukan dalam rangka meningkatkan kedua sumber penerimaan tersebut adalah dengan melakukan intensifikasi dan ekstensifikasi penerimaan. Upaya ini dilakukan melalui : penyempurnaan peraturan daerah yang mengatur tentang pajak daerah dan retribusi daerah, memperbaiki dan meningkatkan kualitas pelayanan dalam pemungutan dilapangan dan menggali potensi pajak daerah dan retribusi daerah sesuai dengan potensi yang dimiliki Provinsi Jambi.

Upaya yang dilakukan dalam mendorong terjadinya peningkatan penerimaan pajak daerah dan retribusi daerah juga dilakukan Provinsi Jambi upaya memperbaiki sisitem dan prosedur kelambagaan yang terlibat dalam pemungutan penerimaan tersebut, yaitu adanya dibentuk Unit Pelayanan terpadu. Meningkatkan kualitas sumber daya manusia yang terlibat dalam pemungutan, yaitu dengan merekrut tenaga kerja yang spesialisasi di bidang yang dikerjakannya. Upaya lain yang dilakukan adalah menjaga kondisi politik dan keamanan serta mendorong peningkatan kesadaran masyarakat sebagai wajib pajak dalam mematuhi peraturan yang dibuat terkait pajak daerah dan retribusi daerah.

\section{KESIMPULAN DAN SARAN}

\section{Kesimpulan}

Selama periode tahun 2002-2018 di Provinsi Jambi, rata-rata pajak daerah meningkat 17,03 persen, rata-rata retribusi daerah meningkat 16,49 persen, rata-rata belanja daerah meningkat 16,04 persen dan pertumbuhan ekonomi tumbuh rata-rata 5,76 persen.

Secara parsial (individu) maupun secara bersama-sama, pajak daerah dan retribusi daerah berpengaruh positif dan signifikan terhadap belanja daerah Provinsi Jambi pada $\alpha=$ $5 \%$ selama periode tahun 2002-2018.

Secara parsial (individu) maupun secara bersama-sama, pajak daerah dan retribusi daerah berpengaruh positif dan signifikan terhadap pertumbuhan ekonomi Provinsi Jambi pada $\alpha=5 \%$ selama periode tahun 2002-2018. 


\section{Saran}

Penerimaan pajak daerah dan retribusi daerah yang meningkat perlu dipertahankan dan terus ditingkatkan. Upaya yang dapat dilakukakan adalah : melakukan pemungutan secara lebih optimal sesuai potensi, meningkatkan tarif secara berkala agar penerimaan dapat meningkat, melakukan perluasan jenis pajak daerah dan retribusi daerah yang berpotensi untuk dikembangkan dan melakukan pengawasan dalam pemungutan dilapangan.

Adanya pengaruh yang siginfikan penerimaan pajak daerah dan retribusi daerah terhadap belanja daerah, maka perlu adanya upaya meningkatkan penerimaan pajak daerah dan retribusi daerah dengan cara meningkatkan pertumbuhan ekonomi melalui peningkatan aktivitas ekonomi pada setiap sektor setinggi mungkin yang dijadikan sebagai basis pemungutan pajak daerah dan retribusi daerah dan nantinya akan mendorong peningkatan belanja daerah.

Adanya pengaruh pajak daerah dan retribusi daerah terhadap pertumbuhan ekonomi, maka perlu adanya perbaikan dan ketersediaan infrastruktur dalam kegiatan ekonomi, meningkatkan alokasi belanja daerah pada sektor-sektor ekonomi yang mampu meningkatkan barang dan jasa serta mampu menciptakan lapangan kerja untuk meningkatkan kesejahteraan masyarakat dan pertumbuhan ekonomi.

\section{DAFTAR PUSTAKA}

NN. (2020). Provinsi Jambi Dalam Angka Tahun 2015-2019. Diakses dalam http: //bps.go.id, Tanggal 12 Februari 2019, Pukul 10.00 WIB.

Fuad, Moh. Ramli. (2016). Analisis laporan keuangan pemerintah daerah, Ghalia Indonesia, Bogor.

Ghozali, Imam. (2013), Aplikasi analisis multivariate dengan program IMB SPSS, Edisi kelima, Universitas Diponegoro: Semarang.

Gunawan, M, Setyadi. (2018). Model keterkaitan antara pendapatan pajak dan retribusi daerah terhadap alokasi belanja modal yang dimediasi oleh dana bagi hasil pajak serta dimoderasi oleh Kabupaten/ Kota di Indonesia, Jurnal Akuntansi dan Pajak (JAP), 19(1). 53-59

Husna, A. Dan Sofia, M. (2013). Pengaruh pendapatan asli daerah dan dana perimbangan terhadap pertumbuhan ekonomi dalam pengembangan wilayah Kabupaten Bintan Provinsi Kepulauan Riau, Jurnal JEMI, 4(2), 1-12

Juwari, Setyadi. Djoka., \& Ulfah. Yuli. (2016). Pengaruh pajak daerah dan retribusi serta dau dan dak terhadap belanja daerah dan pertumbuhan ekonomi pada kabupaten/kota di wilayah Kalimantan, Jurnal GeoEkonomi, 7(1), 1-15.

Laksono, Bagus Bowo. (2014). Pengaruh pajak daerah, retribusi daerah, dau dan dak terhadap belanja daerah, Accounting Analysis Journal, 3(4). 457-465, https://doi.org/10.15294/aaj.v3i4.4207

Melas, Agus. (2017). Pengaruh pajak daerah dan retribusi daerah terhadap belanja langsung pemerintah daerah (studi pada Kabupaten/Kota Se- Sulawesi Tengah), e Jurnal Katalogis, 5(4), 44-55

Sukirno, Sadono. (2017). Ekonomi pembangunan: proses, masalah dan kebijakan, edisi kedua, Prenada Media: Jakarta.

Undang - Undang No. 33 Tahun 2004 tentang perimbangan keuangan antara pemerintahan pusat dan pemerintahan daerah 